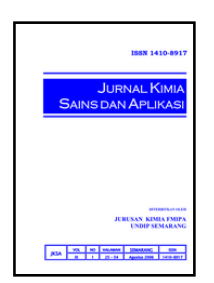

\title{
Pembuatan Dye-Sensitized Solar Cell dengan Memanfaatkan Fotosensitizer Ekstrak Kol Merah (Brassica oleracea var. capitataf. Rubra)
}

\author{
Laila Ika Anggraini ${ }^{\mathrm{a}}$, Abdul Haris ${ }^{\mathrm{a}^{*}}$, Didik Setiyo Widodo ${ }^{\mathrm{a}}$ \\ a Analytical Chemistry Laboratory, Chemistry Department, Faculty of Sciences and Mathematics, Diponegoro University, Jalan Prof. \\ Soedarto, Tembalang, Semarang 50275 \\ * Corresponding author: a.haris@live.undip.ac.id
}

Article Info

Keywords:

Dye Sensitized Solar

Cell, $\mathrm{TiO}_{2}$,

anthocyanin
Kata kunci:

Dye Sensitized Solar Cell, $\mathrm{TiO}_{2}$, antosianin.

\section{Abstract}

A fabrication of Dye Sensitized Solar Cell using a red cabbage extract (Brassica oleracea var, capitataf. Rubra). Dye-Sensitized Solar Cell (DSSC) is one of the potential candidates of solar cells. The process of light absorption is performed by dye molecules and the process of charge separation by $\mathrm{TiO}_{2}$ semiconductors. The natural colouring agent used was isolated in a mixture of acetic acid: methanol: water and then continued by a phytochemical screening. The characterization of red cabbage extract was performed by Vis UV spectrometer and FTIR spectrometer and the $\mathrm{TiO}_{2}$ thin layer characterization was accomplished by X-ray diffraction method and SEM (Scanning Electron Microscopy). The construction of solar cells used was in a sandwich system. The efficiency of DSSC performance was obtained by measuring the voltage and current generated under different conditions i.e. under sunlight and indoors. DSSC component characterization results showed that the red cabbage photosensitizer was a phenolic compound of the flavonoid group. The presence of anthocyanin content was indicated by a maximum wavelength of $525 \mathrm{~nm}$ which was reinforced by the emergence of hydroxyl, benzene and carbonyl groups in infrared absorption. The $\mathrm{TiO}_{2}$ thin layer had a surface morphology with a cavity size of approximately $220 \mathrm{~nm}$, and a cross-sectional thickness of about 300 $\mathrm{nm}$. While the $\mathrm{TiO}_{2}$ thin layer diffractogram showed that $\mathrm{TiO}_{2}$ had an anatase crystalline phase with a crystallite size of $17.366 \mathrm{~nm}$. The maximum voltage and current generated under conditions under sunlight and indoors were $0.627 \mathrm{~V} ; 0.065 \times 10^{-3} \mathrm{~A}$ and $0.152 \mathrm{~V}$; $0.014 \times 10^{-3} \mathrm{~A}$. The efficiency of the solar cell system in this study were $0.003 \%$ and $0.000113 \%$. The result of characterization of current and voltage showed the ability of conversion of light energy into electrical energy.

\section{Abstrak}

Telah dilakukan penelitian mengenai pembuatan Dye Sensitized Solar Cell dengan memanfaatkan ekstrak kol merah (Brassica oleracea var. capitata f. Rubra). Dye-Sensitized Solar Cell (DSSC) merupakan salah satu kandidat potensial sel surya, proses absorpsi cahaya dilakukan oleh molekul zat warna dan proses separasi muatan oleh semikonduktor $\mathrm{TiO}_{2}$. Zat warna alami yang digunakan diisolasi dalam campuran asam asetat:metanol:air dan dilakukan screening fitokimia. Karakterisasi ekstrak kol merah dilakukan dengan spektrometer UV Vis dan spektrometer FTIR. Karakterisasi lapis tipis $\mathrm{TiO}_{2}$ dilakukan menggunakan metode difraksi sinar-X dan SEM (Scanning Electron Microscopy). Konstruksi sel surya yang digunakan adalah sistem sandwich. Efisiensi kinerja DSSC diperoleh melalui pengukuran voltase dan arus yang dihasilkan pada kondisi yang berbeda yakni di bawah pancaran sinar matahari dan di dalam ruangan. Hasil karakterisasi komponen DSSC menunjukan bahwa fotosensitizer ekstrak kol merah 
merupakan senyawa fenolik golongan flavonoid. Adanya kandungan antosianin ditunjukan dengan panjang gelombang maksimum $525 \mathrm{~nm}$ dan diperkuat dengan munculnya gugus hidroksil, benzena dan karbonil pada serapan inframerah. Lapis tipis $\mathrm{TiO}_{2}$ menunjukkan morfologi permukaan dengan ukuran rongga sekitar $220 \mathrm{~nm}$, dan ketebalan penampang lintang sekitar $300 \mathrm{~nm}$. Sedangkan difraktrogram lapis tipis $\mathrm{TiO}_{2}$ menunjukkan bahwa $\mathrm{TiO}_{2}$ memiliki fasa kristalin anatase dengan ukuran kristal sebesar $17,366 \mathrm{~nm}$. Voltase maksimum dan kuat arus maksimum yang dihasilkan pada kondisi di bawah pancaran sinar matahari dan di dalam ruangan masing-masing sebesar 0,627 $\mathrm{V}$; 0,065.10 $0^{-3} \mathrm{~A}$ dan $0,152 \mathrm{~V} ; 0,014 \cdot 10^{-3} \mathrm{~A}$. Efisiensi yang dihasilkan sistem sel surya dalam penelitian ini masing-masing sebesar 0,003 \% dan 0,000113\%. Hasil karakterisasi arus dan voltase memperlihatkan kemampuan konversi energi cahaya menjadi energi listrik.

\section{Pendahuluan}

Penggunaan energi melalui sel surya merupakan salah satu alternatif yang potensial dari sekian banyak sumber energi terbaharukan. Sel surya bekerja menggunakan energi matahari dengan mengkonversi secara langsung radiasi matahari menjadi listrik. Seiring dengan perkembangan nanoteknologi, sel surya secara bertahap mulai tergantikan dengan kehadiran generasi terbaru, yaitu Dye-Sensitized Solar Cell (DSSC).

DSSC diperkenalkan pertama kali oleh Michael Gratzel dan Brian O'Regan pada tahun 1991 dan dikenal dengan nama Sel Gratzel [1]. Pada DSSC absorpsi cahaya dan separasi muatan listrik terjadi pada proses yang terpisah. Absorpsi cahaya dilakukan oleh molekul zat warna yang sensitif terhadap cahaya dan separasi muatan oleh semikonduktor anorganik nanokristalin [2]. DSSC berbentuk struktur sandwich, dua elektroda yaitu elektroda $\mathrm{TiO}_{2}$ tersensitisasi dye dan elektroda lawan terkatalisasi mengapit elektrolit membentuk sistem sel fotoelektrokimia. Dalam aplikasi DSSC, $\mathrm{TiO}_{2}$ harus memiliki permukaan luas sehingga zat warna yang teradsorpsi lebih banyak dan hasilnya akan meningkatkan arus listrik. Selain itu penggunaan bahan zat warna yang mampu menyerap spektrum cahaya yang lebar dan cocok dengan pita energi $\mathrm{TiO}_{2}$ juga merupakan karakteristik yang penting.

Pada awalnya, sensitizer yang digunakan dalam penelitian Prairie $d k k$. [3] adalah zat warna rutenium. Namun penggunaan senyawa kompleks logam dapat menyebabkan pengaruh negatif pada lingkungan. Oleh karena itu, para peneliti mulai memanfaatkan senyawasenyawa yang berasal dari alam dalam aplikasinya sebagai sensitizer DSSC. Penggunaan bahan-bahan alam ini bertujuan untuk meminimalisasi dampak buruk terhadap lingkungan dan menekan biaya produksi sehingga dapat dihasilkan sel surya yang murah dan ramah lingkungan.

Ekstrak dye atau pigmen tumbuhan yang digunakan sebagai sensitizer dapat berupa ekstrak klorofil, karoten atau antosianin. Sensitizer yang pernah digunakan dalam sistem DSSC di antaranya buah berry [4], senyawa antosianin dalam bunga Rosella [5], strawberi [6] dan buah delima [7]. Zat warna alami tersebut telah terbukti mampu memberikan efek fotovoltaic walaupun efisiensi yang diberikan masih jauh lebih kecil dibandingkan zat warna sintetik. Meskipun demikian, zat warna organik sangat kompetitif untuk dijadikan sensitizer karena biaya produksinya yang lebih murah dan proses isolasi lebih mudah.

Kol merah (Brassica oleracea var. capitata f. Rubra) merupakan salah satu buah yang mengandung pigmen antosianin dan belum banyak penelitian yang mengupas penggunaannya sebagai sensitizer. Warna merah pada kol merah mengindikasikan adanya kandungan pigmen antosianin di dalamnya, sehingga dapat digunakan sebagai sensitizer. Pada penelitian ini dipilih senyawa antosianin dalam ekstrak kol merah sebagai pewarna alternatif dari kompleks ruthenium.

Teknologi pembuatan Dye-Sensitized Solar Cell (DSSC) yang dikembangkan pada penelitian ini diharapkan bisa menjadi studi awal untuk penelitian lebih lanjut sehingga menghasilkan sel surya yang mempunyai performansi lebih baik, dapat lebih memasyarakatkan Dye-Sensitized Solar Cell (DSSC) sebagai alternatif sel surya yang murah dan ramah lingkungan.

\section{Metode}

Penelitian ini menggunakan bahan sebagai berikut: $\mathrm{TiO}_{2}$ merck, kol merah, polyvinyl alcohol (pva), metanol proanalisis, asam asetat proanalisis, kalium iodida (ki) proanalisis, iodin $\left(\mathrm{I}_{2}\right)$ proanalisis. asetonitril proanalisis. serbuk karbon, isolasi, akuades, kertas saring, alumunium foil. Alat yang akan digunakan sebagai berikut: Pipet volum $10 \mathrm{~mL}, 25 \mathrm{~mL}$ dan $50 \mathrm{~mL}$, Peralatan gelas, Batang pengaduk, Lumpang porselain, Furnace, Spektrometer UV-Vis, Scanning Electron Microscopy (SEM) jeol jsm-6360 LA, Difraktometer sinar X pan analytical, Spektrofotometer Inframerah Thermo Nicolet Avatar 360, Multimeter Heles, Potensiometer Alpha 10k, Penjepit buaya, Kaca konduktif (TCO) jenis ITO (Indium tin oxide).

\section{Pembuatan Pasta $\mathrm{TiO}_{2}$}

Pada tahap ini $\mathrm{TiO}_{2}$ dibuat dalam bentuk pasta agar bisa dilapiskan pada substrat kaca, yaitu dengan prosedur pembuatan sebagai berikut:

1. Polivinil Alkohol (PVA) ditambahkan sebanyak $10 \%$ berat ke dalam air, kemudian diaduk pada temperatur $80^{\circ} \mathrm{C}$. Suspensi ini akan berfungsi sebagai binder dalam pembuatan pasta. Suspensi 
tersebut ditambahkan pada bubuk $\mathrm{TiO}_{2}$ sebanyak kurang lebih $10 \%$ volume.

2. Derajat viskositas pasta untuk mendapatkan pasta yang optimal didapatkan dengan mengatur banyaknya binder dan juga bila diperlukan ditambahkan juga air pada campuran binder dan bubuk $\mathrm{TiO}_{2}$.

\section{Deposisi $\mathrm{TiO}_{2}$ pada Substrat Kaca Berkonduksi}

1. Pada substrat kaca TCO yang telah dipotong menjadi ukuran 2,5 x 2,5 cm dibentuk area tempat $\mathrm{TiO}_{2}$ dan dideposisikan dengan bantuan isolasi pada bagian kaca yang konduktif sehingga terbentuk area sebesar $2 \times 1,5 \mathrm{~cm}$ dengan ilustrasi seperti pada gambar 1. Isolasi ini juga berfungsi sebagai pengatur ketebalan pasta $\mathrm{TiO}_{2}$.

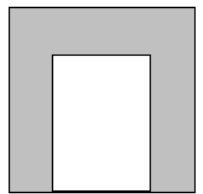

Gambar 1. Ilustrasi Skema Area Deposisi Pasta $\mathrm{TiO}_{2}$

Pasta $\mathrm{TiO}_{2}$ dideposisikan di atas area yang telah dibuat pada kaca konduktif dengan metoda slip casting yaitu dengan bantuan batang pengaduk untuk meratakan pasta. Kemudian lapisan dikeringkan selama kurang lebih 15 menit dan dibakar (sintering) dalam furnace pada temperatur $450^{\circ} \mathrm{C}$ selama 30 menit.

\section{Karakterisasi Lapis Tipis $\mathrm{TiO}_{2}$}

Karakterisasi morfologi dan tebal tampang lintang lapis tipis $\mathrm{TiO}_{2}$ dilakukan dengan Scanning Electron Microscopy (SEM) dan struktur kristal dari $\mathrm{TiO}_{2}$ dianalisis dengan X-Ray Diffractometer. Sedangkan gugus-gugus yang terdapat dalam lapis tipis $\mathrm{TiO}_{2}$ dianalisis dengan spektrometri inframerah.

\section{Isolasi Zat Warna Alami}

Sebanyak 20 gram kol merah dihaluskan kemudian ditambahkan metanol:asam asetat:air (25:4:21 perbandingan volume). Kemudian dimaserasi selama 24 jam dan wadah ditutup dengan alumunium foil untuk meminimalkan kontak langsung dengan cahaya. Lalu dilakukan penyaringan untuk memperoleh ekstrak zat warna alami.

\section{Karakterisasi Zat Warna Ekstrak Kol Merah}

Profil absorpsi zat warna ekstrak kol merah dianalisis dengan menggunakan spektrometer UV-Vis dengan panjang gelombang cahaya pada $400 \mathrm{~nm}-700$ nm. Sedangkan gugus-gugus fungsi yang terdapat dalam zat warna ekstrak kol merah dianalisis spektrometeri FTIR pada bilangan gelombang 4000-400 $\mathrm{cm}^{-1}$.
Perendaman Zat Warna Kol Merah pada Lapis Tipis $\mathrm{TiO}_{2}$

Lapisan $\mathrm{TiO}_{2}$ direndam dalam larutan zat warna kol merah (Impatiens balsamina) selama \pm 30 menit kemudian lapisan $\mathrm{TiO}_{2}$ akan menjadi berwarna ungu kemerahan.

Karakterisasi Serapan Inframerah Lapis Tipis $\mathrm{TiO}_{2}$ dan Zat Warna Alami.

Ikatan kimia yang terjadi antara $\mathrm{TiO}_{2}$-zat warna ditunjukkan dengan munculnya atau hilangnya pita serapan inframerah yang baru ketika zat warna teradsorp pada lapis tipis $\mathrm{TiO}_{2}$

\section{Pembuatan Larutan Elektrolit}

Kalium Iodida (KI) sebanyak 0,83 g dilarutkan dalam $10 \mathrm{~mL}$ asetonitril kemudian diaduk sampai larut. Setelah itu tambahkan $0,127 \mathrm{~g} \mathrm{I}_{2}$ kedalam larutan tersebut dan diaduk hingga larut sempurna.

\section{Pembuatan Elektroda Lawan}

Polyvinyl Alcohol (PVA) sebanyak $10 \%$ berat ditambahkan ke dalam akuades, kemudian diaduk pada temperatur $80^{\circ} \mathrm{C}$. Suspensi ini akan berfungsi sebagai binder dalam pembuatan pasta. Kemudian suspensi tersebut ditambahkan pada serbuk grafit. Pasta grafit dilapiskan ke substrat kaca pada bagian konduktif kemudian dipanaskan pada temperatur $450^{\circ} \mathrm{C}$ selama 10 menit agar grafit membentuk kontak yang baik sesama partikel grafit dan dengan substrat kaca konduktif.

\section{Pembuatan Konstruksi DSSC}

Setelah masing-masing komponen DSSC berhasil dibuat kemudian dilakukan perangkaian konstruksi DSSC dengan langkah-langkah sebagai berikut:

Elektroda kerja $\mathrm{TiO}_{2}$ kemudian diletakkan di atas elektroda lawan grafit dengan struktur sandwich dan masing-masing ujung diberi offset sebesar $0,2 \mathrm{~cm}$ untuk kontak elektrik. Kemudian agar struktur sel mantap dijepit dengan klip pada kedua sisi.

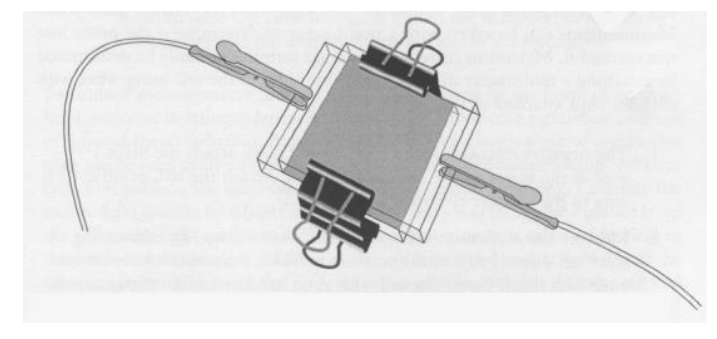

Gambar 2. Konstruksi sel surya

Larutan elektrolit kemudian diteteskan kira-kira sebanyak 2 tetes pada ruang antara kedua elektroda dan sel surya siap untuk diuji.

\section{Pengujian Sel Surya}

Pada sel surya yang telah dirangkai dilakukan dua jenis pengujian yaitu, pengujian langsung tegangan dan arus yang terukur dari sel surya dengan menggunakan multimeter Heles pada kondisi pancaran cahaya matahari langsung dan di dalam ruangan. 
Pada penelitian ini dilakukan pembuatan Dye Sensitized Solar Cell dalam skala laboratorium dengan memanfaatkan ekstrak kol merah (Brassica oleracea var. capitataf. Rubra) sebagai fotosensitizer. Karakteristik lapis tipis $\mathrm{TiO}_{2}$ dilakukan melalui karakterisasi morfologi permukaan dan penampang lintang lapis tipis $\mathrm{TiO}_{2}$ dengan Scanning Electron Microscopy (SEM) dan karakterisasi fase kristal lapis tipis $\mathrm{TiO}_{2}$ dengan difraksi sinar X. Analisis absorpsi zat warna ekstrak kol merah menggunakan spektrometri UV-Vis. Sedangkan untuk mengkaji terjadinya ikatan antara lapis tipis $\mathrm{TiO}_{2}$-zat warna dilakukan melalui analisis serapan inframerah. Selain itu dilakukan pengukuran arus dan tegangan dengan variasi resistansi untuk memperoleh efisiensi DSSC pada kondisi di dalam ruangan dan di bawah pancaran sinar matahari langsung.

\section{Hasil dan Pembahasan}

\section{Karakteristik Fase Kristal Lapis Tipis $\mathrm{TiO}_{2}$}

Analisis dengan metode difraksi sinar X dilakukan untuk menentukan fase dan ukuran kristal penyusun lapis tipis $\mathrm{TiO}_{2}$. Pada difraktrogram menunjukkan puncak pada $2 \theta$ yaitu 25,$409 ; 37,912 ; 48,163 ; 55,185$; 62,825 dan diperoleh jarak antarbidang (d) sebesar

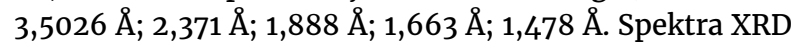
hasil analisis kemudian dibandingkan dengan data standar primer $\mathrm{TiO}_{2}$ dari ICSD (Inorganic Crystal Structure Database). Hasil yang didapatkan menunjukkan bahwa fase kristal $\mathrm{TiO}_{2}$ hasil XRD adalah anatase setelah dibandingkan dengan data primer $\mathrm{TiO}_{2}$ yang memiliki puncak $2 \theta$ pada 25,$28 ; 37,80 ; 48,047 ; 55,058 ; 62,686$. Dengan menggunakan persamaan Scherrer pada indeks bidang miller (101), ukuran kristal yang terhitung yaitu $17,366 \mathrm{~nm}$.

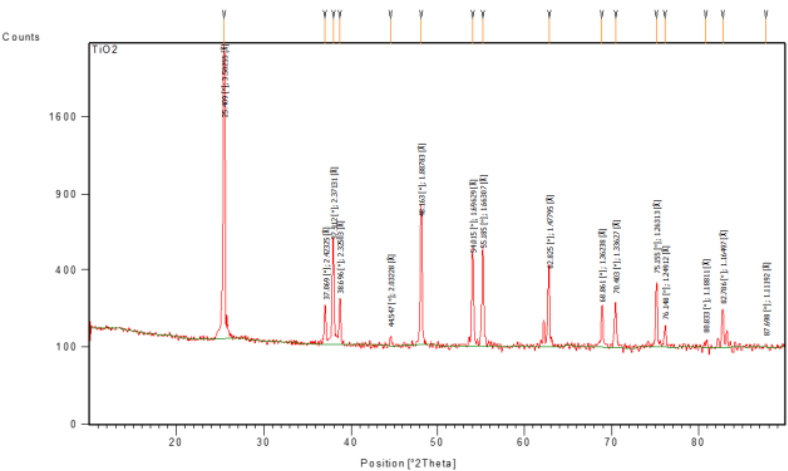

Gambar 3. Pola XRD elektroda $\mathrm{TiO}_{2}$

Derajat kristalinitas sampel ini cukup baik dilihat dari intensitas puncak difraksi yang tinggi dan tegas. Dengan derajat kristalinitas yang baik maka proses difusi elektron di $\mathrm{TiO}_{2}$ akan lebih cepat. Struktur kristal anatase memiliki aktivitas yang paling baik di antara fasa rutile dan brookite [8]. Hal tersebut dikarenakan transport muatan pada kristal anatase akan lebih mudah. Luas permukaan pada anatase mampu menghasilkan daya adsorpsi yang efektif terhadap molekul pewarna.

\section{Karakterisasi Morfologi Lapis Tipis $\mathrm{TiO}_{2}$}

Morfologi permukaan serta tebal tampang lintang lapis tipis $\mathrm{TiO}_{2}$ dapat diketahui melalui analisis SEM (Scanning Electron Microscopy). Struktur nanopori $\mathrm{TiO}_{2}$ merupakan karaktersitik penting dalam DSSC, karena posisi dye akan berada pada pori-pori tersebut. Hasil analisis SEM lapis tipis $\mathrm{TiO}_{2}$ disajikan pada gambar 4 . Pada perbesaran yang lebih tinggi terlihat morfologi permukan lapis tipis yang berongga-rongga (gambar 4b).

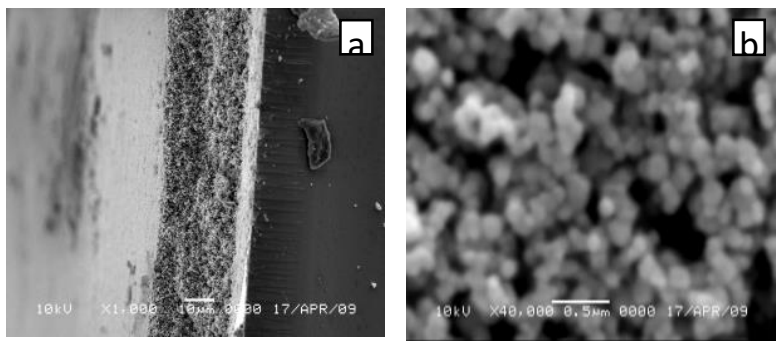

Gambar 4. Penampang lintang lapis tipis $\mathrm{TiO}_{2}$ dengan pembesaran 1.000x (a) dan Morfologi permukaan lapis tipis $\mathrm{TiO}_{2}$ dengan pembesaran $5.000 \mathrm{x}(\mathrm{b})$

Rongga-rongga tersebut memiliki ukuran $220 \mathrm{~nm}$. Morfologi lapis tipis yang berongga-rongga akan memperbesar permukaan lapis tipis $\mathrm{TiO}_{2}$ sehingga zat warna dapat teradsorpsi secara efektif pada ronggarongga lapis tipis $\mathrm{TiO}_{2}$ tersebut. Selain itu adanya rongga juga bisa mempermudah penyebaran larutan elektrolit dalam lapis tipis $\mathrm{TiO}_{2}$ elektroda kerja sel surya.

Karakterisasi Serapan Inframerah Lapis Tipis $\mathrm{TiO}_{2}$

Analisis dengan spektroskopi inframerah dilakukan dengan tujuan untuk mengetahui gugus-gugus fungsional yang ada pada serbuk $\mathrm{TiO}_{2}$. Dengan mengetahui gugus-gugus yang terdapat pada lapis tipis $\mathrm{TiO}_{2}$ diharapkan kita dapat memprediksi ikatan maupun interaksi yang mungkin terjadi antara zat warna dengan permukaan lapis tipis $\mathrm{TiO}_{2}$. Pada gambar 5. memperlihat spektra FTIR pada lapis tipis $\mathrm{TiO}_{2}$ sebelum tersensitisasi oleh zat warna. Spektra FTIR yang diperoleh menunjukan puncak yang lebar pada daerah 676,94493,78 $\mathrm{cm}^{-1}$ diidentifikasikan sebagai kerangka kerja $\mathrm{TiO}_{2}$ (Ti-O-Ti). Sementara itu, puncak yang muncul pada $3417,86 \mathrm{~cm}^{-1}$ merupakan karakteristik gugus hidroksi.

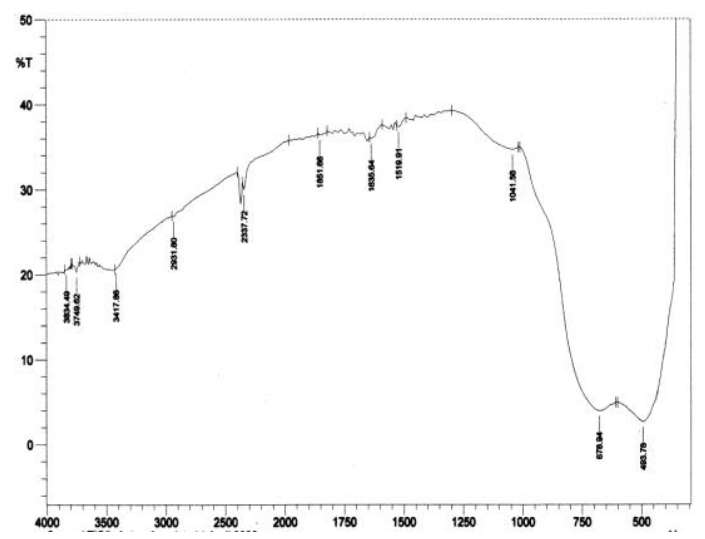

Gambar 5. Spektra FTIR Lapis Tipis $\mathrm{TiO}_{2}$ 
Ekstraksi Zat Warna dari Kol Merah (Brassica oleracea var. capitata f. Rubra)

Penggunaan pigmen antosianin pada DSSC dikarenakan kemampuan antosianin dalam menyerap cahaya tampak dan sebagai donor elektron dalam proses transfer elektron. Pada proses maserasi, cairan penyari akan menembus dinding sel dan masuk ke dalam rongga sel yang mengandung zat aktif . Zat aktif akan larut karena adanya perbedaan konsentrasi antara larutan zat aktif di dalam sel dan di luar sel, maka larutan yang terpekat di desak keluar. Peristiwa tersebut berulang sehingga terjadi keseimbangan konsentrasi antara larutan di luar dan di dalam sel.

Selama proses perendaman dalam campuran pelarut, kontak dengan cahaya diminimalisasi untuk menghindari kerusakan gugus kromofor yang terdapat pada senyawa antosianin yang digunakan untuk berikatan dengan $\mathrm{TiO}_{2}$. Larutan pewarna hasil ekstraksi berwarna merah. Hal ini sejalan dengan penelitian Xavier dkk. [9] bahwa antosianin akan berwarna kemerahan pada suasana asam dan berada pada bentuk kesetimbangan flavylium.

\section{Analisis Absorpsi Zat warna Kol Merah}

Sumber radiasi sistem DSSC adalah sinar matahari yang menghasilkan spektra lebih banyak di daerah tampak daripada di daerah UV, oleh karena itu dibutuhkan zat warna yang dapat menyerap pada daerah cahaya tampak. Analisis absorpsi cahaya oleh zat warna antosianin pada kol merah dilakukan dengan spektrometri UV-Vis pada rentang panjang gelombang $400 \mathrm{~nm}-700 \mathrm{~nm}$.

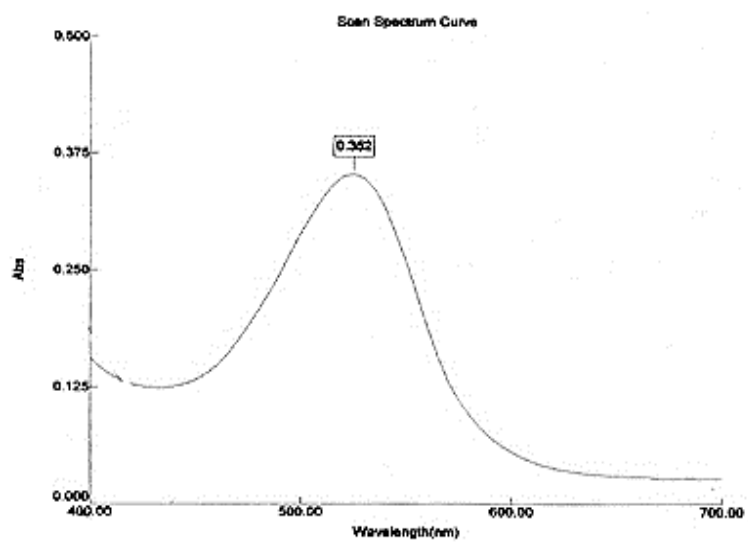

Gambar 6. Grafik UV-Vis dye pada ekstrak kol merah

Gambar 6 memperlihatkan bahwa spektrum serapan ekstrak antonsianin cukup lebar yang mencakup dari pita biru hingga hijau (450-570 nm) dengan panjang gelombang maksimum pada sekitar 525 nm. Oleh karena itu, zat warna antosianin pada kol merah berwarna merah karena menyerap spektrum biru-hijau dan memantulkan warna merah. Hal ini menandakan bahwa pigmen antosianin yang ada pada kol merah dapat mengabsorbsi cahaya dengan panjang gelombang yang masih dalam spektrum cahaya tampak.
Karakterisasi Gugus Fungsional Zat warna Ekstrak Kol Merah

Analisis dengan spektroskopi inframerah dilakukan dengan tujuan untuk mengetahui gugus-gugus fungsional yang ada pada zat warna ekstrak kol merah sehingga dapat diperkirakan ikatan maupun interaksi antara zat warna dengan permukaan $\mathrm{TiO}_{2}$.

Zat warna yang dapat digunakan sebagai sensitiser adalah zat warna yang dapat teradsorpsi dan memiliki gugus fungsional yang dapat berikatan secara kimia dengan permukaan $\mathrm{TiO}_{2}$ [4]. Kisi $\mathrm{Ti}^{\mathrm{IV}}$ pada permukaan $\mathrm{TiO}_{2}$ akan berikatan dengan gugus $\mathrm{C}=\mathrm{O}$ dan $-\mathrm{OH}$ pada antosianin yang digunakan sebagai zat warna. Zat warna utama yang terdapat pada kol merah adalah Cyanidin-3diglucoside-5-glucoside [10] yang merupakan senyawa fenolik golongan flavonoid. Hal ini dibuktikan pula dengan perlakuan screening fitokimia yang menunjukan uji positif terhadap senyawa fenolik golongan flavonoid. Senyawa golongan fenolik tersusun atas satu cincin benzena atau lebih dengan 1 atau lebih gugus hidroksil $(-\mathrm{OH})$.

Spektra FTIR ekstrak kol merah ditunjukan pada gambar 4.6 muncul serapan pada $3444.27 \mathrm{~cm}^{-1}$ melebar kemungkinan adanya gugus fungsi $\mathrm{OH}$ yang dapat membentuk suatu ikatan hidrogen. Adanya gugus $\mathrm{C}=\mathrm{O}$ ditunjukkan oleh pita lebar pada daerah 1712,86 $\mathrm{cm}^{-1}$. Gugus karbonil ini muncul karena adanya kesetimbangan senyawa antosianin yang berada dalam bentuk sianidin quinonoidal. Serapan 1015,79 cm-1 menunjukkan adanya gugus $\mathrm{C}-\mathrm{O}$. Pita serapan pada $1643.10 \mathrm{~cm}^{-1}$ merupakan serapan $\mathrm{C}=\mathrm{C}$ alkena. Pita lebar $569,23 \mathrm{~cm}^{-1}$ menunjukkan subtitusi atom karbon tak jenuh. Sehingga serapan pada daerah $1643,10 \mathrm{~cm}^{-1}$ yang didukung adanya serapan $569,23 \mathrm{~cm}^{-1}$ menunjukkan adanya gugus benzena.

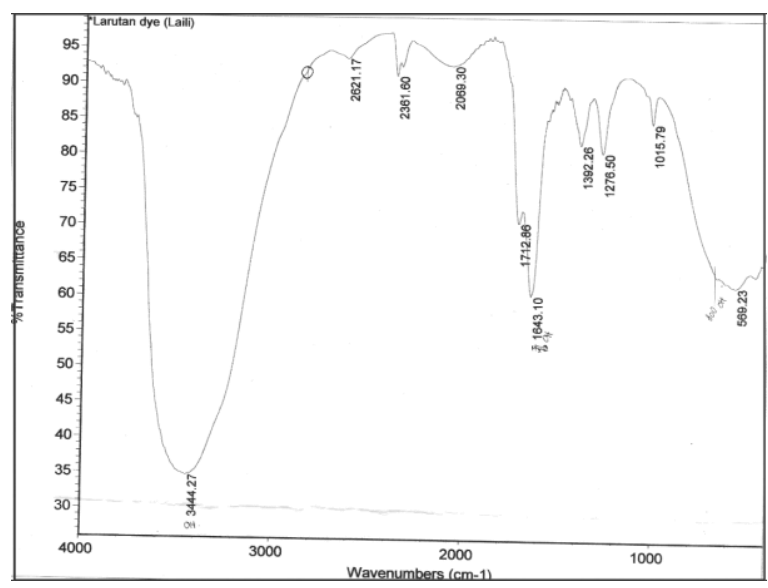

Gambar 7. Spektra FTIR zat warna ekstrak kol merah

\section{Karakterisasi Serapan Inframerah $\mathrm{TiO}_{2}$-Zat warna}

Analisis spektrometri inframerah terhadap lapis tipis $\mathrm{TiO}_{2}$-zat warna dilakukan untuk mengetahui apakah serapan yang muncul pada lapis tipis $\mathrm{TiO}_{2}$-zat warna menunjukkan terbentuknya suatu ikatan kimia pada $\mathrm{Ti}^{4+}$ dengan zat warna. Ikatan kimia yang terjadi ditunjukkan dengan munculnya atau hilangnya pita 
serapan yang baru antara lapis tipis $\mathrm{TiO}_{2}$ dan zat warna kol merah dengan campuran lapis tipis $\mathrm{TiO}_{2}$-zat warna.

Lapisan $\mathrm{TiO}_{2}$ direndam dalam larutan zat warna kol merah kemudian lapisan $\mathrm{TiO}_{2}$ akan menjadi berwarna ungu kemerahan. Spektra lapis tipis $\mathrm{TiO}_{2}$-zat warna pada gambar 8 menunjukkan pita kuat di daerah 3450,17 $\mathrm{cm}^{-1}$ yang merupakan gugus $\mathrm{OH}$. Sedangkan pita tajam $1644,90 \mathrm{~cm}^{-1}$ menunjukkan rentangan gugus $\mathrm{C}=\mathrm{C}$. Pita lebar $518,81 \mathrm{~cm}^{-1}$ menunjukkan subtitusi atom karbon tak jenuh. Sehingga serapan pada daerah $1644,90 \mathrm{~cm}^{-1}$ yang didukung adanya serapan 518,81 $\mathrm{cm}^{-1}$ menunjukkan adanya gugus benzena. Adanya gugus $\mathrm{C}=\mathrm{O}$ ditunjukkan oleh pita lebar pada daerah $1721,34 \mathrm{~cm}^{-}$ ${ }^{1}$. Puncak yang lebar pada daerah $689,15 \mathrm{~cm}^{-1}$ yang muncul pada spektrta FTIR diidentifikasikan sebagai kerangka kerja $\mathrm{TiO}_{2}$ (Ti-O-Ti). Ikatan yang terjadi antara zat warna dengan $\mathrm{TiO}_{2}$ merupakan jembatan yang menghubungkan zat warna dengan $\mathrm{TiO}_{2}$ untuk terjadinya injeksi elektron dari zat warna menuju pita konduksi pada $\mathrm{TiO}_{2}$. Oleh karena itu dengan terjadinya ikatan tersebut diharapkan zat warna kol merah dapat mensensitisasi $\mathrm{TiO}_{2}$.

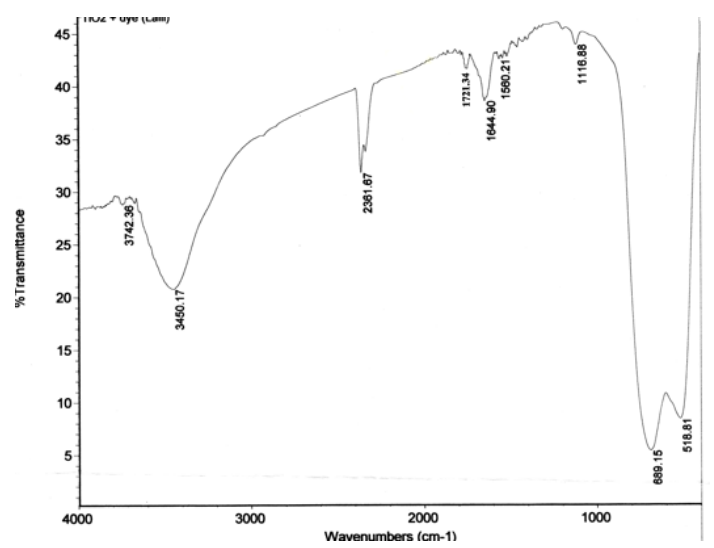

Gambar 8. Spektra FTIR lapis tipis $\mathrm{TiO}_{2}$-zat warna

Tabel 1. Data pita serapan antara lapis tipis $\mathrm{TiO}_{2}$ dan zat warna dengan lapis tipis $\mathrm{TiO}_{2}$-zat warna

\begin{tabular}{|c|c|c|c|}
\hline \multicolumn{3}{|c|}{ Bilangan gelombang $(\mathrm{cm}-1)$} & \multirow[b]{2}{*}{ Jenis vibrasi } \\
\hline $\begin{array}{c}\text { Lapis tipis } \\
\underset{\mathrm{TiO}_{2}}{ }\end{array}$ & $\begin{array}{c}\text { Zat } \\
\text { warna }\end{array}$ & $\begin{array}{c}\text { Lapis tipis } \\
\mathrm{TiO}_{2}-\mathrm{zat} \\
\text { warna }\end{array}$ & \\
\hline 3417,86 & 3444,27 & 3450,17 & $\begin{array}{l}\text { OH membentuk } \\
\text { ikatan hidrogen }\end{array}$ \\
\hline- & 1643,10 & 1644,90 & $\mathrm{C}=\mathrm{C}$ \\
\hline- & 1712,86 & 1721,34 & $\mathrm{C}=\mathrm{O}$ \\
\hline- & 1015,79 & - & $\mathrm{C}-\mathrm{O}$ \\
\hline- & 569,28 & 518,81 & Subtitusi benzen \\
\hline $\begin{array}{c}676,94^{-} \\
493,78\end{array}$ & - & 689,15 & $\begin{array}{l}\text { Kerangka kerja } \\
\mathrm{TiO} 2(\mathrm{Ti}-\mathrm{O}-\mathrm{Ti})\end{array}$ \\
\hline
\end{tabular}

Ikatan kimia antara zat warna dengan $\mathrm{TiO}_{2}$ kemungkinan terjadi antara gugus hidroksi dan karbonil pada cyanidin yang ada dalam ekstrak kol merah dengan ion Ti(IV). Mekanisme reaksi adsorpsi zat warna pada permukaan $\mathrm{TiO}_{2}$ dapat dilihat pada gambar 9 .

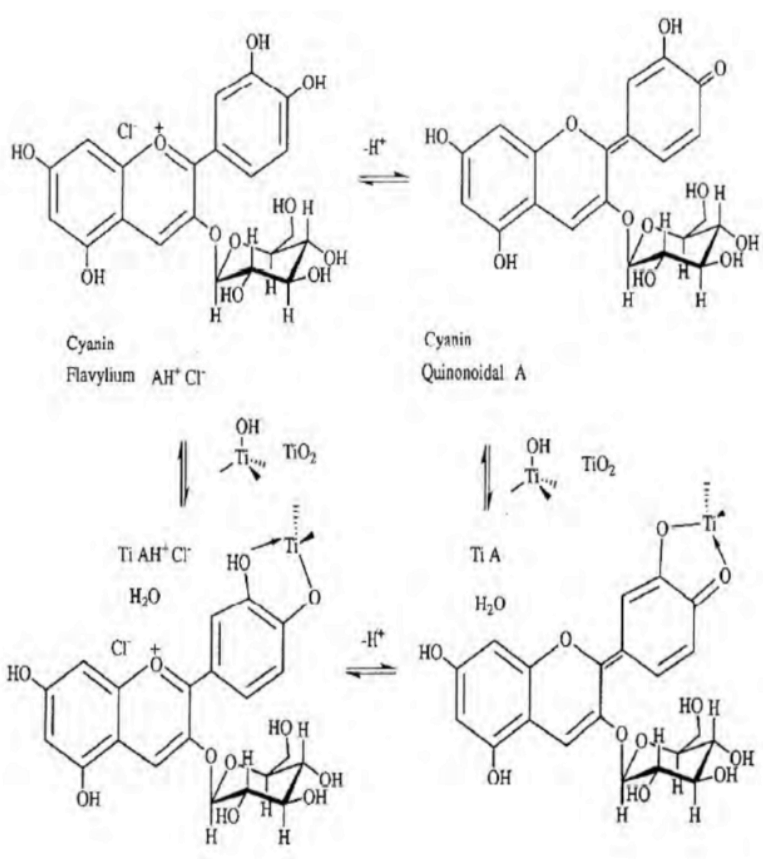

Gambar 9. Adsorpsi zat warna pada permukaan $\mathrm{TiO}_{2}$ [11]

\section{Penentuan Kinerja Sel Surya}

Penentuan efisiensi DSSC dilakukan dengan metode kurva arus dan tegangan. Tujuan penentuan efisiensi DSSC adalah untuk mengetahui keefektifan satu susunan komponen DSSC dalam mengubah energi matahari menjadi energi listrik yang dinyatakan dalam persen. Pada penelitian ini pengukuran dilakukan di dalam ruangan dan di bawah pancaran sinar matahari. Hal ini bertujuan membandingkan pengaruh keberadaan sinar matahari terhadap performansi sel surya.

Kinerja sel surya tersensitisasi zat warna sangat dipengaruhi oleh foton yang terabsorp oleh zat warna dan konstruksi sel surya yang meliputi elektroda lawan, elektroda kerja dan elektrolit. Elektroda kerja dalam sistem DSSC merupakan lapisan $\mathrm{TiO}_{2}$ tersensitisasi zat warna yang dilapiskan $\mathrm{di}$ atas substrat kaca berkonduksi. Substrat kaca yang digunakan adalah kaca TCO (Trnsparant Conductive Oxide) yang dilapisi indium tin oxide ( $\mathrm{In}_{2} \mathrm{O}_{3}: \mathrm{Sn}$ atau ITO). Pada penelitian ini substrat kaca yg digunakan berasal dari kaca LCD. Konstruksi sel surya dibuat dengan sistem sandwich dengan luas aktif sel surya 1,5x $2 \mathrm{~cm}^{2}$.

Pengaruh sinar matahari pada kinerja sel surya tersensitisasi zat warna ekstrak kol merah terlihat dengan dihasilkannya arus listrik pada kondisi pancaran sinar matahari yang lebih tinggi bila dibandingkan dengan arus listrik yang dihasilkan pada kondisi di dalam ruangan. Hal ini disebabkan cahaya matahari mempunyai intensitas cahaya yang lebih tinggi selain itu spektrum cahaya yang dipancarkan lebih lebar. Oleh karena itu cahaya matahari merupakan sumber iluminansi yang paling efektif untuk pengujian. Kurva tegangan vs kuat arus sel surya pada kondisi pancaran sinar matahari (a) dan kondisi di dalam ruangan disajikan pada gambar 10. 

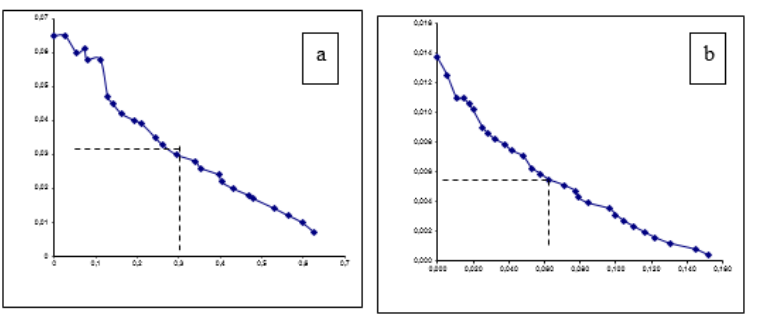

Gambar 10. Kurva V vs I sel surya pada kondisi pancaran sinar matahari (a) dan kondisi di dalam ruangan (b).

Tegangan yang dihasilkan berasal dari perbedaan tingkat energi konduksi elektroda semikonduktor $\mathrm{TiO}_{2}$ dengan potensial elektrokimia pasangan elektrolit redoks $\left(\mathrm{I}^{-} / \mathrm{I}_{3}^{-}\right)$. Sedangkan arus yang dihasilkan dari sel surya ini terkait langsung dengan jumlah foton yang terlibat dalam proses konversi dan bergantung pada intensitas penyinaran serta kinerja dye yang digunakan.

Tabel 2. Hasil pengukuran arus-voltase sel surya

\begin{tabular}{cccccc}
\hline $\begin{array}{c}\text { Substrat } \\
\text { DSSC }\end{array}$ & $\begin{array}{c}V_{O C} \\
(\mathrm{~V})\end{array}$ & $\begin{array}{c}I_{S C}(\mathrm{I}) \\
\mathrm{X} \mathrm{10}^{-3}\end{array}$ & $F F$ & $\begin{array}{c}P_{\operatorname{MAX}} \\
(\mathrm{W})\end{array}$ & $\eta(\%)$ \\
\hline $\begin{array}{c}\text { pancaran } \\
\text { sinar } \\
\text { matahari }\end{array}$ & 0,627 & 0,065 & 0,221 & $\begin{array}{c}9,01 \times \\
10^{-6}\end{array}$ & $\begin{array}{c}3,003 \\
\times 10^{-3}\end{array}$ \\
$\begin{array}{c}\text { dalam } \\
\text { ruangan }\end{array}$ & 0,152 & 0,014 & 0,161 & $\begin{array}{c}3,42 \times \\
10^{-7}\end{array}$ & $\begin{array}{c}1,13 \times \\
10^{-4}\end{array}$ \\
\hline
\end{tabular}

Keterangan: $V_{O C}=$ tegangan open circuit, $I_{S C}=$ arus short circuit, $V_{M P P}=$ tegangan saat daya maksimum, $I_{M P P}=$ arus saat daya maksimum, FF = Fill Factor, $P_{\text {MAX }}=$ daya maksimum yang dihasilkan dari sel, $\eta=$ efisiensi sel surya.

Parameter sel surya yang didapatkan dari kurva I vs V disajikan dalam Tabel 2. Dari tabel terlihat bahwa sel surya dalam penelitian ini memiliki harga kerapatan arus listrik $\left(\mathrm{J}_{\mathrm{sc}}\right)$ yang relatif kecil. Efisiensi yang dihasilkan pada kondisi di bawah sinar matahari sebesar $3,003 \times 10^{-3} \%$ dan pada kondisi di dalam ruangan sebesar $1,13 \times 10^{-4} \%$.

Nilai efisiensi yang kecil disebabkan oleh beberapa faktor. Kompetisi antara proses injeksi elektron dari keadaan tereksitasi ke pita konduksi $\mathrm{TiO}_{2}$ dengan proses rekombinasi yang tidak diinginkan sehingga menghasilkan arus yang kecil. Elektrolit yang digunakan mempunyai waktu penggunaan yang pendek karena mudah rusak dan menguap karena panas. Hal ini sangat mempengaruhi efisiensi, karena proses donasi elektron kepada zat warna yang teroksidasi akibat injeksi elektron tidak akan berlangsung maksimal, sehingga zat warna tidak dapat kembali ke ke keadaan ground state. Selain itu sistem sandwich sel surya hanya diletakkan dengan menggunakan penjepit kertas sehingga ada kemungkinan terjadi penguapan elektrolit selama pengukuran berlangsung. Meskipun kinerja sel surya ditentukan dengan material yang masih sederhana, akan tetapi setidaknya dalam penelitian ini sudah berhasil mengkonversi energi surya menjadi energi listrik

\section{Kesimpulan}

Hasil karakterisasi komponen DSSC menunjukan bahwa sensitizer ekstrak kol merah merupakan senyawa fenolik golongan flavonoid. Adanya kandungan antosianin ditunjukan dengan panjang gelombang maksimum $525 \mathrm{~nm}$ dan diperkuat dengan munculnya gugus hidroksil, benzena dan karbonil pada serapan inframerah. Lapis tipis $\mathrm{TiO}_{2}$ menunjukkan morfologi permukaan dengan ukuran rongga sekitar $220 \mathrm{~nm}$, dan ketebalan penampang lintang sekitar $300 \mathrm{~nm}$. Sedangkan difraktrogram lapis tipis $\mathrm{TiO}_{2}$ menunjukkan bahwa $\mathrm{TiO}_{2}$ memiliki fasa kristalin anatase. DSSC yang dihasilkan dengan memanfaatkan ekstrak kol merah sebagai sensitizer berhasil mengkonversi energi surya menjadi energi listrik dengan efisiensi pada pancaran sinar matahari sebesar 3,003. $10^{-3} \%$ dan di dalam ruangan sebesar $1,13 \times 10^{-4} \%$.

\section{Daftar Pustaka}

[1] Michael Gratzel, Photoelectrochemical cells, Nature, 414, 6861, (2001) 338-344

[2] M Grätzel, AJ McEvoy, Principles and applications of dye sensitized nanocrystalline solar cells (DSC), Asian J. Energ. Env, 5, (2004) 197-210

[3] Michael R. Prairie, Albert Renken, James G. Highfield, K. Ravindranathan Thampi, Michael Grätzel, A fourier transform infrared spectroscopic study of C02 methanation on supported ruthenium, Journal of Catalysis, 129, 1, (1991) 130-144 https://doi.org/10.1016/0021-9517(91)90017-X

[4] Greg P Smestad, Michael Gratzel, Demonstrating electron transfer and nanotechnology: a natural dye-sensitized nanocrystalline energy converter, J. Chem. Educ, 75, 6, (1998) 752

[5] Khwanchit Wongcharee, Vissanu Meeyoo, Sumaeth Chavadej, Dye-sensitized solar cell using natural dyes extracted from rosella and blue pea flowers, Solar Energy Materials and Solar Cells, 91, 7, (2007) 566-571

https://doi.org/10.1016/j.solmat.2006.11.005

[6] I. Thaithae, Tipparach, U., dan Pukird, S, Effects of Natural Dyes On The Efficiency Of Dye Sensitized TiO2 Nanocrystalline Solar Cells, Thai Journal of Physics, Series 3, 77, (2008)

[7] PM Sirimanne, MKI Senevirathna, EVA Premalal, PKDDP Pitigala, V Sivakumar, K Tennakone, Utilization of natural pigment extracted from pomegranate fruits as sensitizer in solid-state solar cells, Journal of Photochemistry and Photobiology A: Chemistry, 177, 2, (2006) 324-327

[8] Oana Carp, Carolien L Huisman, Armin Reller, Photoinduced reactivity of titanium dioxide, Progress in solid state chemistry, 32, 1, (2004) 33-177

[9] Marcelo Fonseca Xavier, Toni Jefferson Lopes, Mara Gabriela Novy Quadri, Marintho Bastos Quadri, Extraction of red cabbage anthocyanins: optimization of the operation conditions of the column process, Brazilian archives of Biology and technology, 51, 1, (2008) 143-152 
[10] Gordon J McDougall, Stewart Fyffe, Pat Dobson, Derek Stewart, Anthocyanins from red cabbagestability to simulated gastrointestinal digestion, Phytochemistry, 68, 9, (2007) 1285-1294

[11] Nerine J Cherepy, Greg P Smestad, Michael Grätzel, Jin Z Zhang, Ultrafast electron injection: implications for a photoelectrochemical cell utilizing an anthocyanin dye-sensitized $\mathrm{TiO} 2$ nanocrystalline electrode, The Journal of Physical Chemistry B, 101, 45, (1997) 9342-9351 